\title{
UNA PIEZA SECRETA: JUEGOS Y JUGUETES EN LA NARRATIVA DE ADOLFO COUVE ${ }^{1}$
}

\author{
Felipe Toro Franco ${ }^{2}$ \\ Universidad de Chile \\ felipetorofranco@gmail.com
}

\section{RESUMEN / ABSTRACT}

Este ensayo propone leer la narrativa de Adolfo Couve desde las referencias al juego, los juguetes y la infancia. A partir de esto, se explora el modo en que las novelas cortas de Couve se construyen apropiándose del mundo perdido de los niños chilenos de ayer (la revista $E l$ peneca, los dibujos de Coré, trenes de cuerda, etc).

Palabras Clave: juegos, juguetes, Couve, infancia en novela chilena.

This essay reads Adolfo Couve's narrative through the notions of game, toys and childhood. In doing so, we explore the ways in which Couve's short novels obliquely quote the lost world of past Chilean childhood and its beloved objects (El peneca magazine, drawings by the artist Coré, wooden trains, etc.).

KEY WORDS: games, toys, Couve, representations of childhood in Chilean novel.

Al revisar la obra narrativa de Adolfo Couve, rara avis del panorama de la novela chilena reciente, el lector experimenta una suerte de extravío, sobre todo al observar los cambios que sufren sus textos. ¿Qué se podría decir de

1 Este texto tiene su origen en el seminario de postgrado "Narrativa de Adolfo Couve", dirigido por el profesor Leonidas Morales.

2 Becario CONICYT. 
sus primeros artefactos narrativos - habitados por hermosos niños como si se tratara de una calculada ensoñación-que hiciera suponer el surgimiento de las Comedias, en donde el texto, paródicamente, parece avanzar hacia su propia disolución? Si sus primeras ejecuciones (tal vez habría que llamarlas así, atendiendo su meticulosa elaboración) daban la idea de ser verdaderos ejercicios de composición donde cada elemento encontraba su correspondencia con un todo armónico, donde cada pieza parecía coincidir o encontrar su calce perfecto $^{3}$; a partir de La comedia del arte (1995) el discurso obsesivo se desbarata en una festividad que extrae sus principales recursos del registro oral: "Hablar, hablar, hablar del tema como si la boca tuviera un racimo de lenguas, los tentáculos de un pulpo" (404). Los relatos de Couve ofrecen un ambiguo placer: la casi total ausencia de anécdota en sus textos obliga a estar, continuamente, interrogando la propia lectura o, en palabras de Barthes, a leer levantando la cabeza, no por desinterés, sino a causa de las asociaciones que genera (35). Lo que sigue son, precisamente, notas en torno al juego (y sus alrededores) surgidas desde esa desprotección en la que los textos de Couve nos sitúan.

Adriana Valdés en su valioso prólogo a Narrativa completa (2003) ha señalado que "si hubiera que imaginar al escritor Couve en una sola escena, [...] lo haría aparecer como el titiritero a cargo de los personajes de [La comedia del arte]. Como alguien que juega con muñecos, pero con muñecos como los de Rilke" ("Adolfo Couve" 10). Desde esta perspectiva-agreguemos-, la literatura de Couve se presenta como una suerte de Retablo de Maese Pedro, la famosa escena de la segunda parte del Quijote. Aquí, al igual que el Ingenioso Hidalgo en compañía de Sancho Panza, el lector asiste, efectivamente, a una presentación de títeres, pero cuyo final no será otro que la completa destrucción de los muñequitos -el mismo destino que sufren los figurines

\footnotetext{
Proponemos, como ejemplo de este esfuerzo en la composición, un fragmento sacado de "La lección de pintura" (1979), donde las luces y sombras del paisaje -por decisión de la autoría- consiguen un artificioso equilibrio: "Sucédense allí en forma alternada profundas sombras y luminosas zonas de sol, tan intensamente estas últimas que en ellas casi se pierde la calidad de la tierra. Los perros se funden con las oscuridades donde se echan. Las aves de corral, en cambio, más inquietas, cruzan veloces hacia la luz, recuperando de golpe sus nítidas siluetas" (Couve 174). El texto como un cuadro que debe mantener su equilibrio (las mañas del pintor): si los perros se sitúan en la sombra, entonces graciosamente se colocan a la luz un par de gallinas para hacer de contrapeso.
} 
de Maese Pedro por mano de don Quijote ${ }^{4}-$ exhibiendo así una inquietante materialidad: el cuerpo de cera del pintor Camondo y su cabeza arrancada sin ningún dolor. ¿Qué clase de seres son estos que no sienten dolor? Lo curioso es que al mostrarlo convertido en una estatua de cera, el texto solo se encarga de explicitar, enfática y teatralmente, la verdadera naturaleza de su personaje (antes ya parecía un monigote movido por hilos invisibles en el escenario). Los narradores de Couve -como niños en una pieza secreta- elaboran toda clase de destinos para sus personajes, que transitan sin oponer resistencia a las a veces arbitrarias o disparatadas desventuras a las que son sometidos. De ahí que desde el juego ${ }^{5}$ (el cuarto secreto de la escritura) y los juguetes, tal vez podamos seguirle los pasos a esta narrativa.

Apuntemos que la figura de la cabeza sin cuerpo de La segunda comedia nos recuerda, por asociación libre y por su intención paródica, esa otra "cabeza encantada" - esta vez no por Apolo- que se le presenta a don Quijote en casa de don Antonio Moreno: "Esta cabeza [...] ha sido hecha y fabricada por uno de los mayores encantadores y hechiceros que ha tenido el mundo [...], el cual estuvo aquí en mi casa, y por precio de mil escudos que le di labró esta cabeza [de bronce], que tiene propiedad y virtud de responder a cuantas cosas al oído le preguntaren" (Cervantes 475). Cabezas que deslumbran a quienes la han perdido (Don Quijote en sentido figurado, Camondo en el literal); cabezas ridículas en su solemnidad, empotradas en una escenografía aparatosa, manipuladas con ingenio y artificio (“...entre todos acordaron

4 Creemos necesaria una lectura del humor de Couve desde ciertas secuencias del Quijote y, en particular, la del Retablo de Maese Pedro: “....y diciendo esto desenvainó la espada [Don Quijote], y de un brinco se puso junto al retablo, y con acelerada y nunca vista furia comenzó a llover cuchilladas sobre la titerera morisma, derribando a unos, descabezando a otros, estropeando a este, destrozando a aquel, y entre muchos otros tiró un altibajo tal, que si maese Pedro no se encoge y agazapa, le cercenara la cabeza como si fuera hecha de mazapán [...]. Finalmente, en menos de dos credos dio con todo el retablo en el suelo, hechas pedazos y desmenuzadas todas sus figuras, el rey Marcilio mal herido, Carlo Magno partida la corona y la cabeza en dos partes" (Cervantes 203).

Utilizaremos, como un amplio marco de referencia, la definición que entrega Huizinga del juego: "Resumiendo, podemos decir, por tanto, que el juego, en su aspecto formal, es una acción libre ejecutada "como si" o sentida como situada fuera de la vida corriente, pero que, a pesar de todo, puede absorber por completo al jugador, sin que haya en ella ningún interés material ni se obtenga en ella provecho alguno, que se ejecuta dentro de un determinado tiempo y un determinado espacio, que se desarrolla en un orden sometido a reglas y que da origen a asociaciones que propenden a rodearse de misterio o a disfrazarse para destacarse del mundo habitual" (27). 
confeccionar el muñeco, un San Tarcisio, abrir un espacio bajo el altar mayor..." [Couve, Cuando pienso 458]); cabezas, finalmente, que participan de un humorístico juego teatral.

Y dentro de estas afinidades cervantinas ${ }^{6}$, habría también que considerar los caricaturescos gobernadores coloniales de Couve, Meneses Lisandro (de En los desórdenes de junio) y Zapiola (de El picadero), cuyos desplantes hacen pensar en Sancho Panza rigiendo sobre la ínsula prometida: "Los otros licenciados que habitaban el castillo reían del futuro gobernador y una vez engrudaron un papel en su silla para que Meneses al levantarse se llevara en el trasero un cartelón profano" (En los desórdenes de junio 36); "A la hora de los postres se sirvió sandía y el llavero, sin poder contenerse, escupía las pepas al Gobernador [...]. El llavero, que creyó era ésta una broma, escupió otra andanada de pepas y cáscaras a Zapiola [...]. Todos se escupían y arrojaban comida, volaban las verduras..." ( El picadero 77). Dentro de las obras que recoge el catálogo pictórico de Couve hecho por Claudia Campaña, hay un dibujo de Meneses Lisandro en que lo vemos gordinflón, vestido de gala, marchando con algo que podría ser un catalejo en la mano: nos hacemos la idea de un Sancho Panza embutido en las ropas de Casimiro Marcó del Pont.

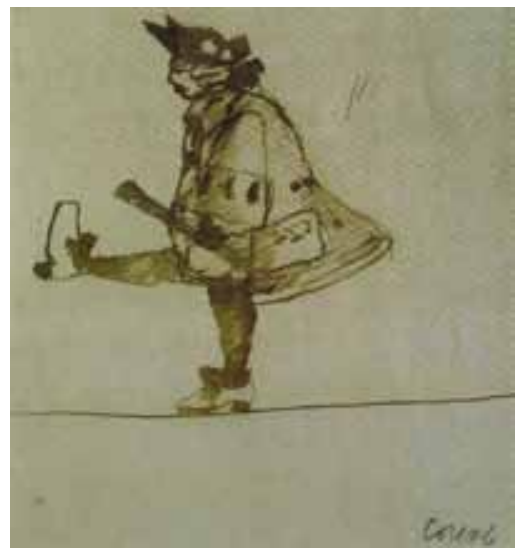

Figura 1, reproducida en Adolfo Couve: una lección de pintura (Campaña 55)

6 Lateralmente, ¿no se parece el mismo título de Cuando pienso en mi falta de cabeza a un verso sacado del Siglo de Oro -de hecho, es un bello endecasílabo-; no parece acaso construido con la retórica de un español que nos suena antiguo? 
Walter Benjamin en el Libro de los pasajes señala: "Cuando Víctor Hugo escribía Los trabajadores del mar, tenía ante sí un muñeco con el traje antiguo de una dama de Guernesey. Se la habían conseguido; ella era para él el modelo de Déruchette" (703). No nos resulta lejana esta afirmación para Couve; no obstante, habría que trastocarla, pues mientras Víctor Hugo parte del modelo (la muñeca) para llegar a la verosimilitud del personaje (Déruchette), Couve partiría desde una supuesta adhesión al realismo para llegar a la muñeca (el modelo) ${ }^{7}$. Así, vemos en Cuando pienso ... al descabezado pintor Camondo, hombre de cera, disfrazarse de fraile: "Volví a la sacristía y, en mi desesperación, hurgué [...] hasta dar con una vieja vestidura que no debió estar mezclada con casullas, albas y estolas. Se trataba de un hábito de San Francisco [...]. Para mí fue la solución, el disfraz, la única forma de completar mi figura..." (436). Difícil no relacionar esta secuencia con la figurita de un santo tallado en madera utilizado por Couve para pintar un óleo llamado, justamente, Santos de madera (Figura 2). Se trata, ciertamente, de una imagen de San Francisco, fácilmente reconocible por el flequillo; no le falta la cabeza, pero sí carece de ambos brazos (la mutilación la comparte con Camondo). Resultaría esquemático buscar una completa identidad entre el Camondo de cera, disfrazado de franciscano, y aquella figurita del San Francisco de madera; antes bien, la relación sirve para ilustrar una cadena significante de cuerpos cosificados en la literatura de Couve, verdaderas naturalezas muertas, objetos en reposo (pequeños tesoros cotidianos) expuestos a la mirada del lector -cabe recordar que una parte considerable de la obra pictórica de Couve se compone de naturalezas muertas y (auto) retratos (Campaña 104).

\footnotetext{
Gesto que evoca el uso del maniquí por parte de ciertos pintores, como es el caso de Poussin, y lo transporta al escenario de la escritura: "...y cuando se trataba de una "historia" más compleja, [Poussin] hacía una escena en planchas, dividida en recuadros, sobre las que disponía figuritas de cera que utilizaba para tal fin [...] y las vestía con papel mojado o con tafetán muy fino, para las ropas, según hiciera falta, y equipaba luego el conjunto con hilos tensados de tal manera que cada figura encontrara su sitio correcto en relación al horizonte" (Leblond de Latour, cit. en Arikha 178).
} 


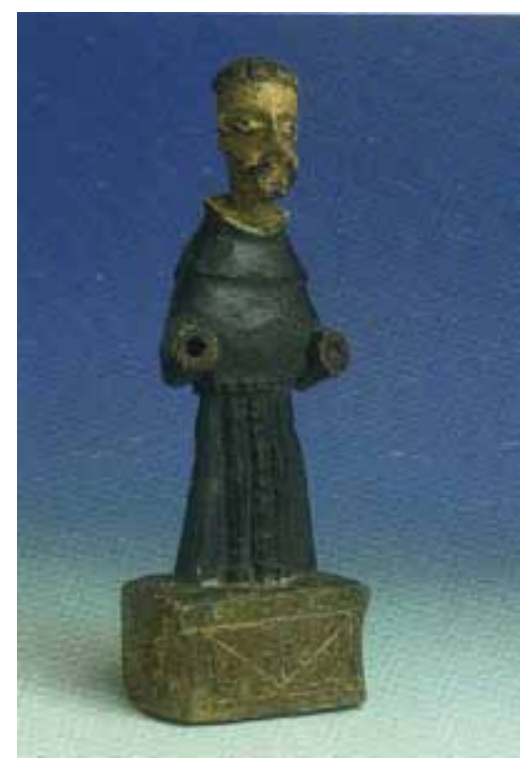

Figura 2, reproducida en Adolfo Couve: una lección de pintura (Campaña 134)

Las cosificaciones no se reducen únicamente a los textos ulteriores de Adolfo Couve, sino que las vemos cruzar buena parte de su obra. De este modo, Blanca Diana será descrita en El picadero como una estatua (por su nombre y palidez, en medio de una casona de campo desierta, ya la asociamos a las clásicas esculturas de Diana la Cazadora que coronan los jardines de casas aristocráticas): "Era muy hermosa, con aquella pregunta que nos hacemos ante las cabezas griegas [...], el mentón, sitio de las emociones, a veces tembloroso y débil, en otras firme y olvidado al cincel de un arcaico artesano" (59); en La lección de pintura, la viuda Medrano es vista a la manera de un juguete: "[S]u aspecto llamaba la atención [...] imprimiendo a su andar y sus ademanes una precisión y rapidez que sólo logran los juguetes mecánicos" (174); en El pasaje, las manos de la señorita Perla Muro "se movían con tal independencia que se pensaba podían girar en redondo, como las de las muñecas de goma" (234). Y si bien, sobre todo en El picadero -donde a la estatua de Blanca Diana se suma el cuerpo incorrupto del efebo Angelino: la nouvelle está construida como un mausoleo familiar-, podríamos ligar este verosímil al grotesco de José Donoso (sus figuras ominosas, sus niños de identidad ambigua), en adelante el mundo de Couve se transforma en 
una suerte de taller de Geppeto. Allí, los personajes muestran de qué están hechos, el lector puede ver sus costuras, aparecen como "parchados"-son juguetes viejos puestos en marcha por la memoria- en un deliberado gesto de composición: "La señora lo recibió en la cama, y solía narrar Madrazo a sus inquilinos, se arrancó de un tirón la peluca, como para advertirle que la visita no se repitiera" (El tren de cuerda 137); "Las cejas, el único detalle firme de su cara, le eran ajenas, como postizas" (137).

Revisemos un fragmento de La lección de pintura que nos llama poderosamente la atención. En él se nos describe al pequeño Augusto Medrano, hijo de aquella viuda cuyos gestos han sido presentados anteriormente a la manera de "un juguete mecánico":

Como la madre, el chico era de contextura frágil. Parecía imposible que esas dos piernecitas flacas como hilos pudieran sostener el cuerpo o, bien, el angosto cuello a la cabeza. De facciones regulares, el cabello negro semejaba pintado por lo sedoso [...]. La boca era diminuta y la nariz tan pequeña y respingada que toda la expresión se la llevaban unos ojos alertas y precisos que no divagaban nunca (176).

¿No es este cuerpo, literalmente, el de una marioneta (los hilos que sostienen la cabeza y las piernas; la cabeza pintada, la boca diminuta como un muñeco; los ojos fijos, sin movimiento)? El pequeño Augusto, a su vez, aparecerá duplicado en un marinero de trapo que lleva en sus manos, y esta figura, por contigüidad, terminará por confirmar la condición de objeto de su dueño, en una dulce puesta en abismo: "Así, Elvira, al regresar, se encontraba con dos niños de expresión idéntica: una accionada por la mano de su dueño; la otra, por la fatiga" (177). Curioso caso en que los sujetos terminan identificándose en última instancia con una cosa, deshumanizándose - proceso que hemos visto también en la conversión de Camondo en estatua de cera o en el referente del San Francisco de madera, que es la forma que asumirá temporalmente el pintor en La segunda comedia. Así, la escritura de Couve se sitúa a mitad de camino, entre la naturaleza muerta - esos objetos sin trascendencia ${ }^{8}-\mathrm{y}$ el (auto) retrato.

8 Tomamos la expresión de Historia de la pintura chilena, de Antonio R. Romera, al referirse a Couve: "Los temas del artista aparecen desposeídos de trascendencia. Son pequeñas obras en las cuales se rinde tributo a las cosas mínimas, a las cosas habituales y cotidianas. Un plato con cuchillo, un vaso, una alcuza. Este intimismo se acentúa por el empleo de un 
Pareciera que en la aparición de estos muñequitos (objetos amados de la infancia) es donde la literatura de Couve alcanza una de sus singularísimas características, a saber: el constante quiebre del pacto ficcional. No es poco común que el lector de Couve sienta que se ha traicionado lo que Umberto Eco definió como "una serie de "señales de género", más o menos perceptibles, que invitan al lector a [...] aceptar los hechos narrativos como si fueran verdaderos" (191). Apuntemos que los narradores de Couve someten al lector a verdaderos "juegos de la decepción" en que lo prometido nunca aparece o, si lo hace, surge de manera contraria a lo esperado (¿dónde está la lección de pintura en La lección de pintura?). El lector de Couve se parece a Anselmo Méric, el niño protagonista de El tren de cuerda, que en la estación de trenes espera pacientemente a su madre que no llegará (128) o que se pasa el día vigilando para ver los globos de colores que un sacerdote había prometido lanzar desde la torre de la parroquia (121) -sobra decir que el sacerdote no cumplirá su promesa.

El desafío de Couve al lector-explicitemos-reside en la tensión paródica que le impone. Sobre la parodia, Giorgio Agamben dirá, en términos similares a los usados por Eco: "Al "como si" de la ficción, la parodia opone su drástico "así es demasiado" (o "como si no"). Por esto, si la ficción define la esencia de la literatura, la parodia se mantiene por así decir en el umbral, tensionada, obstinadamente entre la realidad y la ficción, entre la palabra y la cosa" ("Parodia" 60). La concepción de Agamben -que se aleja de la clásica definición retórica-ayuda a comprender la distancia que el lector adopta con respecto al mundo cosificado de Couve, donde el verosímil constantemente se encarga de desmentirse a sí mismo, de fracasar ficcionalmente (colocándose, por cierto, en esa zona de umbral). Valdés dirá en este mismo sentido: “[Couve] Narra "como si" fuera un escritor realista, pero la falla de este supuesto es delatada por un temblor..." ("Prólogo" 26-7). De allí que con frecuencia -como Fernando Pérez Villalón ha reparado (sin núm.)- descubramos los espacios transformarse en una inverosímil escenografía: "El arco del portón visto desde el pasaje tenía la apariencia de un escenario donde obras anónimas y actores desconocidos se exhibían solo por un instante" (El pasaje 231); "Como un telón de fondo conocido, repuesto una vez más, cuelgan allí en ese verano el azul del cielo y del océano" (Balneario 307); o "me introduje

repertorio cromático hecho de austeridad" (201). Por lo visto, algunos aspectos de la afirmación también caben para su literatura. 
en el parque $[\ldots]$ y pude ver el palacete, una simple fachada de utilería, una maqueta, repleta es cierto de toda clase de ornamentaciones, pero sujeta por atrás con enormes soportes y tirantes de madera" (Cuando pienso en mi falta de cabeza 471). Estos procedimientos -en que el entorno se descubre como una fachada teatral- funcionan, por cierto, de manera deceptiva (un descubrir para defraudarse): el como si del pacto ficcional, al encontrarse con un mundo de utilería (admitido así por el propio texto), sufre una radical desestabilización; el lector camina sobre las aguas, dudando; busca abrigo -desorientado- en las formas.

Hay en las obras de Couve ciertos pasajes que arrojan una luz sobre el gesto de poner en evidencia estas escenografías que rodean a los personajes como un fondo falso. En los textos que componen Cuarteto de la infancia, los niños, junto a otros personajes, juegan a disfrazarse. El tren de cuerda nos ofrece un ejemplo paradigmático:

[Anselmo] le pedía permiso [a Rosarito] para armar escenarios con los muebles, y venciendo su timidez, desvalijaba la sala de baño, para regresar a la salita convertido en corsario o visir. Luego de una profunda reverencia, recitaba versos que al quedar truncos parchaba con otros [...]. Rosarito de vez en cuando dejaba de zurcir y le fijaba sus ojos ausentes (116).

Pequeño teatro rudimentario hecho de objetos de segunda mano; teatro montado en medio de la soledad de la infancia, en la experiencia de la orfandad y el luto (sus madres son viudas o han elegido la viudez, y los niños deben vivir en casas de parientes o protectores lejanos). Juegos, en suma, para soportar el desamparo al interior de esos antiguos caserones de provincia (v.g. El tren de cuerda; La lección de pintura). ¿Será posible, entonces, ver en estos niños que juegan al teatro una muestra a escala de lo que realizan, en el nivel de la enunciación, los narradores de Couve? Agamben, en "El país de los juguetes”, señala: “Un vistazo a los juguetes muestra que los niños, esos ropavejeros de la humanidad, juegan con cualquier antigualla que les caiga en las manos y que el juego conserva así objetos y comportamientos profanos que ya no existen. Todo lo que es viejo [...] es susceptible de convertirse en juguete" (101). Desde este punto de vista, cabe preguntarse, conjeturalmente, si la apropiación de la novela europea del siglo XIX por parte de Couve (y su posterior miniaturización) no corresponde también a un afán por jugar con las viejas ropas -ya pasadas de moda- del baúl del canon occidental. 
Quizás la estrecha relación de la narrativa de Couve con el mundo del juego pueda verse con nitidez en el hecho significativo de que una de sus nouvelles lleve por título precisamente el nombre de un juguete: El tren de cuerda. La motivación del título, como a veces sucede en las obras de Couve, resulta esquiva, ambigua, en una primera lectura. La aparición del trencito de cuerda, regalado por el almirante Azuelos a su protegido, Anselmo Méric, es apenas circunstancial (una sola vez la novela lo nombra; luego, el juguete desaparece). Y, sin embargo, que el relato lleve el título de una miniatura, de inmediato hace poner atención en la deliberada brevedad de este y los demás textos de Couve. Agamben dirá: "Un auto, una cocina eléctrica, una pistola se transforman de golpe, gracias a la miniaturización, en juguetes" ("El país de los juguetes" 101). Atendiendo a la mínima extensión de la obra, ese título (El tren de cuerda) ya no nos resulta tan esquivo. Sobre todo al releer, desde aquí, esa suerte de arte poética que es el prólogo de Cuarteto de la infancia: "[i]ntentar ese engranaje que da como resultado, más que un libro, un verdadero objeto" (Couve 8 ; la cursiva es mía). ¿Podría ser entonces "ese verdadero objeto" un juguete, un tren de cuerda, en sentido literal y figurado?

Walter Benjamin en "Juguetes antiguos" entrega una reflexión en torno al juguete y su lugar en la vida del adulto que puede ser eficaz para aproximarse a la forma de la literatura de Couve:

Es conocida la escena de la familia bajo el árbol de navidad: el padre profundamente concentrado en jugar con el trencito que le acaba de regalar a su hijo, mientras este lo observa llorando. Si el adulto se ve invadido por semejante impulso a jugar, ello no es producto de una simple regresión a lo infantil. Es cierto que el juego siempre libera. Rodeados de un mundo de gigantes, los niños al jugar crean uno propio, más pequeño; el hombre, brusca y amenazadoramente acorralado por la realidad, hace desaparecer lo terrorífico en esa imagen reducida. Así se le resta importancia a una existencia insoportable (82).

Hacer desaparecer lo terrorífico de la realidad en la imagen reducida del juguete: quisiéramos leer allí la clave para entender estas novelas liliputienses, compactas como un objeto y aisladas del mundo exterior (el adulto concentrado en los movimientos del trencito). Lo terrorífico - conjurado allí- nos devuelve a la lectura de Adriana Valdés cuando advierte: "[E]l trasfondo de incomodidad de las narraciones de Couve, que provocan una inquietante sensación de inminente desastre-como si detrás de cada bibelot acechara una posible monstruosidad, como si lo más familiar fuera a la vez lo más amenazante" "“Adolfo Couve" 
11). Si los textos de Couve no se aproximan aún más al grotesco donosiano ${ }^{9}$ -cuya base teórica proviene de Lo grotesco: su configuración en pintura y literatura, de Wolfgang Kayser-pareciera ser porque la parodia y el juego (su absorto ir y venir) en cierta forma lo neutralizan y disipan.

Ahora bien, una vez vistos los juguetes, cabe preguntarse por sus dueños, por esos singulares niños que protagonizan las primeras nouvelles de Couve (El picadero, El tren de cuerda, La lección de pintura, El pasaje). ¿Quiénes son esos seres solitarios, vestidos de señoritos de época, poseedores de una extraña dignidad que los mantiene distantes con el mundo (inhóspito) que los rodea, pequeños santitos de vida contemplativa? Lucen estáticos y misteriosos cual estampillas de primera comunión -y quizá por eso pueda verse una última reminiscencia de ellos en el San Tarcisio (joven mártir de la cristiandad) que arman en la parroquia de Cuncumén con la cabeza de Camondo (eso sí, rejuveneciéndolo con afeites). Angelicales y nimbados por una seriedad que los transforma en una suerte de viejos chicos (puer senex), niños de otro tiempo; baste decir que dos de ellos se llaman, significativamente, Angelino (un ángel) y Augusto (una pequeña dignidad caminante). Así, se nos dice en El tren de cuerda que el rostro de Pavel, el mayordomo, se iluminaba al ver a Anselmo "como ante la visión de un ángel" (128) o que Rogelio, en El pasaje, "adquiría esa palidez y su pelo rubio, sus ojos azules y su inseparable chaleco encendido se desteñía, tomando él, gracias a su inmovilidad y la pobreza circundante, la apariencia de un ángel" (229). Soledades infantiles, también; vidas que se han construido en el desamparo: "La nariz respingada y el labio superior fino hacían al rictus curvarse, lo que le daba un aire despectivo, casi insolente, como de alguien profundamente herido que ya no espera nada de nadie" (El pasaje 214).

Sobre el origen de estos niños, una pista de lectura la encontramos al inicio de El tren de cuerda: "Durante el trayecto [la madre] se mostró especialmente solícita, intentando satisfacer los más pequeños caprichos de su hijo. Anselmo, a pesar de sus atenciones, estuvo reticente, limitándose a aceptar una bebida gaseosa [...] y una revista infantil con ilustraciones muy destacadas" (112; énfasis mío). Más adelante, se dice: "El niño, que como lector asiduo de la revista El peneca conocía algunas biografías, podía

9 Es Leonidas Morales quien ha trabajado las fecundas relaciones entre Donoso y Couve: las viejas que pululan por estos espacios cerrados; las casas y escenarios ruinosos que terminan por convertirse en alegorías identitarias del sujeto (e.g. la Casa de Ejercicios de $E l$ obsceno pájaro de la noche y las pensiones y casas habitadas por esperpentos terminales en La comedia del arte, entre otros vasos comunicantes). 
competir con los rudimentarios conocimientos de Madrazo" (144). Desde mi perspectiva, las páginas de Couve -cuya prosa obsesionada con la sencillez y pulcritud llega a colindar con la simpleza de los cuentos de niños ${ }^{10}$ - en estas novelitas recuperan y reconstruyen el mundo creado por las revistas infantiles, principalmente el de El peneca. El narrador de El tren de cuerda dirá: "[A]sí, esa ciudad plana daba la impresión de una lámina para un cuento de Hadas" (121); o "El silencio del lugar, su aspecto, daban la sensación de una vieja lámina, un telón de fondo para una escena bucólica" (135). De este modo, a la manera de reminiscencias textuales, los niños de Couve parecen sacados de las ilustraciones infantiles hechas por Coré (seudónimo del artista visual Mario Silva Ossa) para El peneca o el famoso Silabario hispanoamericano (también ilustrado por él): esos dibujos de óvalos rosados, rasgos finos, rostros de una contenida tristeza, a veces sumidos en una absorta ensoñación o entregados a la lectura de un libro, nos recuerdan la silenciosa existencia de los niños de Couve, además de compartir con ellos la claridad y definición de sus cuerpos: "Allí, el niño, en el mesón, junto al pupitre de su madre aprendía a trazar palotes y vocales, para luego deletrear, a media voz, con el fin de no perturbar al señor Aguiar, sus primeras lecciones" (La lección de pintura 184); "[E]l niño se trasladaba a la salita, y ahí, de bruces sobre la alfombra hacía sus tareas hasta que la penumbra borroneaba el contorno de las cosas" (El tren de cuerda 114).

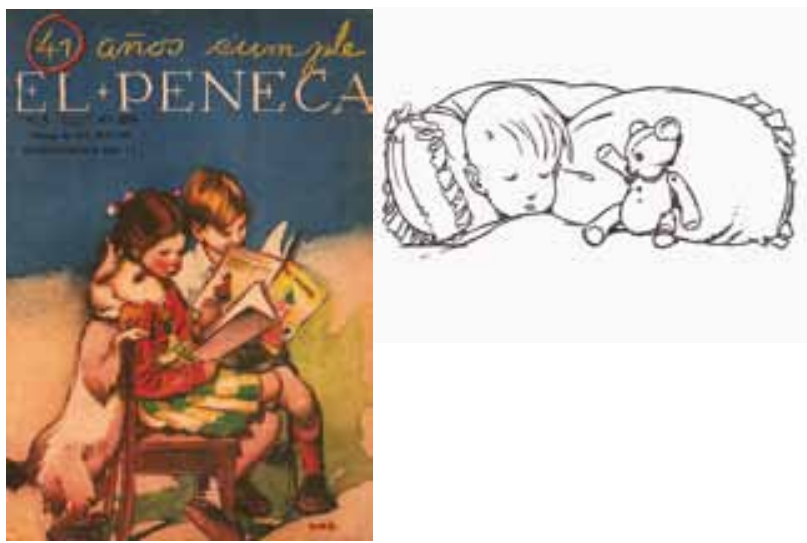

Figuras 3 y 4, reproducidas en Coré (Coré sin núm.)

10 Leonidas Morales, además, ha leído sugerentemente La lección de pintura como un texto que recupera la estructura del cuento de hadas, desde los aportes de Vladimir Propp en Morfología del cuento. 
Casi se podría hacer el ejercicio de yuxtaponer las ilustraciones de Coré con las descripciones de Couve, de manera que estas quedaran a modo de apostillas, como notas al pie de la imagen, dilucidándose mutuamente en su atmósfera compartida, sin necesidad de que calcen punto por punto en el nivel de la anécdota: "Eso era al comienzo, cuando Elvira, al regresar de sus andanzas, lo encontraba dormido en el fondo, abrazado a un marinero de trapo" ( $L a$ lección de pintura 175); "Por las tardes, Rogelio tomó la costumbre de ir al almacén. Allí se formaban tertulias, motivadas por el célebre concurso de una fábrica de caramelos, que distribuía unos álbumes para pegar en ellos pequeñas láminas [...]. Engrudaba en la cocina esas estampas, y cambiaba [...] aquéllas que en los sobres venían repetidas" (El pasaje 233).

Manuel Peña Muñoz en Historia de la literatura infantil chilena dice sobre Coré: "Sus ilustraciones resultan lejanas, impregnadas de melancolía" (54). Estas estampas coloreadas, al parecer, tuvieron no poco impacto en los niños de la época (niños que, una vez crecidos, propondrán la revaloración artística de la obra de Mario Silva Ossa). Así lo atestigua Enrique Lihn ${ }^{11}$ en el artículo "Revista El Peneca: la magia de Coré":

Otra cosa ocurre con Coré, el cual en ese mismo contexto [de una revista infantil con intenciones didácticas] y participando, sin duda, dócilmente de esos códigos, encontró de alguna manera su fórmula mágica, una retórica que produce su efecto y que es, evidentemente, rescatable. Gentes de varias generaciones lo sienten así: de la mía, el historiador de arte y pintor Alberto Pérez; de la que sigue, el pintor y escritor Adolfo Couve, quien ha hecho clases sobre Coré... (527-28).

De la huella de Coré en Adolfo Couve ha quedado un seminario de investigación que dirigió en 1983 en la Universidad de Chile llamado "Coré al museo" (el documento, aún lamentablemente inédito e inexplicablemente ignorado en la recopilación de sus escritos sobre arte, tiene la apariencia de ser un conjunto de reflexiones de Couve "profesor", surgidas en clase, recopiladas y luego

11 Lihn dedica otro artículo a Coré donde afirma: "El típico dibujante mediocre de cuentos infantiles, de cualquier país y de la misma época de Coré -no nombraré a nadie en particular-, era un pretendido fotógrafo del texto [...]. Si ése fue el procedimiento de Coré, lo superó con creces, pues sus dibujos se recuerdan como si fueran textos y él un narrador autónomo, un narrador personaje, una primera persona o, si se quiere, un estilo" ("El retorno de Coré" 467-8). El texto de Lihn finaliza destacando: “[C]oré no fue sólo el poeta visual de una generación meramente infantil" (472). 
ordenadas por los alumnos). Releerlo hoy -desde los niños de Couve, desde su narrativa- significa entrar en el espacio genealógico de desplazamientos e identificaciones de su literatura (un espacio de espejos y citas). Allí leemos: "Sus personajes [de Coré] y la ambientación donde se desenvuelven, parecen detenidos en el tiempo [...]. Se hacen atemporales, adquiriendo vida propia y se hacen autosuficientes con respecto al entorno cronológico relatado" (Abussabbha et al. 13). ¿No participan acaso también de esa atemporalidad los textos de Couve, sus pequeños que flotan en un escenario apartado de las circunstancias históricas ("Aguiar, un tanto habituado a la indumentaria de los pintores malditos de Montmartre, quedó encantado con la apariencia un tanto anacrónica de su pupilo [La lección de pintura 189])? "Coré", dice el seminario, "capta la época en lo sustancial del relato, dejando de lado lo accesorio o anecdótico; transformándolo en una visión personal y universal a la vez" (16). Aquí recordamos, por supuesto, a Couve diciendo en una entrevista: "Detesto lo anecdótico y me carga la imaginación. No la he ocupado nunca" (“Autorretrato de artista”, sin núm.).

Sobre la forma, estas notas acerca de Coré también parecieran despejar ciertos aspectos de la obra de Couve: "[La línea en Coré] es de un trazo limpio y cerrado [...] sin llegar a abrirse jamás [...]. Mientras la forma se abre por efectos de la luz, la línea se mantiene cerrada. Esto deja comprimidas las formas que parecieran sólo respirar por el color" (Abussabbha et al. 11); más adelante se insiste: "[a]pesar de la luz, la forma permanece cerrada: la línea siempre retiene a la luz" (14). Mundos afines, correspondencias formales y temáticas (nuestro escritor hizo girar cuatro novelas alrededor de la etapa de la niñez); y en el prólogo de Cuarteto de la infancia, Couve se referirá a su propia obra en casi los mismos términos: "[o]btuve del neoclasicismo una novela de preciso diseño, un arabesco estricto, una forma cerrada, un formato asfixiante como si una máquina neumática hubiera extraído el aire" (9; énfasis mío). Por simple asociación, la irradiación de Coré y El peneca sobre Couve nos trae a la memoria la importante influencia que tuvo para la narrativa de Julio Cortázar sus tempranas lecturas de El tesoro de la juventud (una suerte de enciclopedia infantil), según interpreta Saúl Yurkievich, al calificarla ya de "formativa" (Otra flor amarilla 20) o relacionarla ya directamente con la estructura de sus obras ("Mate, tango y metafísica" 5).

Agreguemos, además, un apunte especulativo: un hecho biográfico de la leyenda de Coré pudo haber fascinado a Couve por la filiación con su imaginario y su propia definición como artista (este hecho se encuentra consignado en el seminario y, además, en los artículos de Enrique Lihn). 
Los estudios de Walt Disney le ofrecieron a Coré trabajar con ellos, pero él se rehusó. En las páginas del seminario se comenta (y allí creemos escuchar claramente la voz de Couve): "[r]echazando no sólo un lucrativo sueldo sino que además a una empresa que representaba la cima, la relación con las técnicas más modernas [...], Coré se impone una senda independiente, seria y comprometida..." (Abussabbha et al. 13). En esta renuncia, ¿no estará viendo Couve allí, también, su trayectoria (su proyecto alejado de las modas, su persistencia excéntrica que se escabulle del éxito masivo)? Desde esta identificación podría releerse el siguiente fragmento de La comedia del arte: "Al aproximarse a la escalera [...] [Camondo] observó un gran ruedo de gente $[. .$.$] . Al centro, un hombre calvo [...] dibujaba con un palo sobre la$ humedad de la arena [...]. Con la destreza de un Rafael [...] trazaba grandes Patos Donalds, Minnies, Mickeys, Dráculas y Dumbos [...]. La muchedumbre anonadada lanzaba monedas..." (370).

Con todo, si en las nouvelles de la infancia de Couve nos encontramos con niños e imágenes alusivas al mundo de las revistas infantiles, y con formas narrativas que adoptan la característica pequeñez de los juguetes (El tren de cuerda), sin embargo, en el nivel de la enunciación, se observa una meticulosa contención expresiva, ¿dónde entonces puede estar el placer del juego en esa llamada al orden? Roger Caillois, en Los hombres y los juegos, advierte que los juegos, en general, se ubican entre dos polos de tensión. Uno de ellos lo denomina ludus, que consiste en "el gusto por la dificultad gratuita" (65), "por inventar reglas y plegarse a ellas obstinadamente, cueste lo que cueste" (67), donde "interviene el placer de resolver una dificultad creada" (68). Caillois señala, además: "El ludus da ocasión a un entrenamiento y normalmente desemboca en la conquista de una habilidad determinada, en la adquisición de una maestría particular" (68). En las nouvelles de Couve que componen Cuarteto de la infancia se observa esa inclinación al ludus, patente en el prólogo que escribió en 1996: "Guardando las distancias, cuando comencé a escribir me tracé una meta [una regla] [...]: quería alcanzar una prosa depurada, convincente, unos renglones donde tuviera que corregir y corregir, aprender a hacer bien la tarea..." (8; la cursiva es mía). El paso de esta escritura a las Comedias (o a lo que Adriana Valdés ha distinguido como "la segunda etapa" ["Adolfo Couve" 10]) es susceptible de ser interpretado - proponemos-como el paso del ludus al paidia, el otro polo del juego. Caillois lo define como la instancia de "las manifestaciones espontáneas del instinto del juego [...]. [Allí] Interviene toda exuberancia dichosa que manifiesta una agitación inmediata y desordenada, una recreación espontánea y relajada, naturalmente 
excesiva, cuyo carácter improvisado y descompuesto sigue siendo [...] la única razón de ser" (66). La enunciación de La comedia del arte, situada en el distendido festín de Mimí d’Alborio (“¿Me alcanzas la alcuza?” [395]), en el registro oral, en la anécdota desmembrada y antojadiza, nos pone en este plano. El paidia, anota Caillois, "[f]ácilmente se constituye en gusto de destruir o romper. Explica el placer de cortar interminablemente papel con tijeras, hacer trizas una tela, de hacer que se derrumbe un montaje..." (66). En este mismo sentido, Baudelaire dirá que, tarde o temprano, el destino de todo juguete es ser destruido: "El niño da vueltas y más vueltas a su juguete, lo araña, lo agita, lo golpea contra las paredes, lo tira al suelo" ("La moral del juguete" 196-7).

Convirtiendo la escena de su escritura en un espacio de agitación y estruendo -vemos allí la cabeza cortada de Camondo, el retablo de Maese Pedro hecho añicos, las formas armónicas volar por los aires-, Couve al final de su obra se acerca a formas más primarias de juego: la musa de $L a$ comedia del arte disfraza su brebaje para Camondo en el sobre de un jugo Yupi, onomatopeya de la alegría y diversión infantil (además de una marca de bebidas en polvo, poco saludable y destinada a los sectores populares: estamos en Cartagena); o incluso, escuchamos a los personajes hablar como si estuvieran insertos en una tira cómica: “ ¿Todavía crees, zopenco, pedazo de alcornoque, que...?" (La comedia del arte 400). Formas, si se quiere, más evidentemente relacionadas con el juego. De ahí que -no por nada- las peripecias rocambolescas del decapitado Camondo en Cuando pienso en mi falta de cabeza encuentren tantas similitudes con un texto de Julio Cortázar, homo ludens paradigmático de la literatura latinoamericana. En Historias de cronopios y famas, hay un breve cuento humorístico llamado "Acefalia":

A un señor le cortaron la cabeza, pero como después estalló una huelga y no pudieron enterrarlo, este señor tuvo que seguir viviendo sin cabeza y arreglárselas para bien o mal. En seguida notó que cuatro de los cinco sentidos se le habían ido con la cabeza. Dotado de tacto, pero lleno de buena voluntad, el señor se sentó en un banco de la plaza Lavalle y tocaba las hojas de los árboles una por una, tratando de distinguirlas y nombrarlas. Así, al cabo de varios días pudo tener la certeza de que había juntado sobre sus rodillas una hoja de eucalipto, una de plátano, una magnolia foscata y una piedrita verde (41).

El texto de Couve, en primera persona, dice: 
[c]uando aquella musa [...] condujo a Marieta, mi vieja modelo, hasta el altillo de la residencial, permitiéndole arrancar mi pesada cabeza de mis hombros, yo permanecí en esa torre aún con vida [...]; todo indicaba que era imposible el más insignificante atisbo de vida en tan categórico despojo y, sin embargo, en ese montón de cera esta porfiaba y subsistía [...]. Anduve a trastabillones, las manos palpando irregularidades, los accidentes de ese balneario antiguo. Este deambular me condujo a las rocas del Capri, atravesando las negras arenas de la playa chica, la que reconocí por su reducida distancia (435-6).

Finalmente, escenas paradójicas, escándalos de la razón y la lógica. ¿No decía Agamben que la parodia estaba siempre en el límite, en el umbral? La paradoja de estos decapitados, que provocan una risa nerviosa, reside en su posición liminar entre la vida y la muerte, en la personificación de un tercer término entre dos alternativas incompatibles; muertos en vida que deben arreglárselas como puedan: volver al tacto, al trato primario con los objetos. Couve y Cortázar aquí comparten lo que podríamos denominar una gramática, un modo de juego, aunque uno y otro se sitúen en veredas opuestas (Couve, en el final de su escritura, con un proyecto centrado en lo local, en la provincia; Cortázar, cosmopolita, ligado a la vanguardia, a los divertimentos surrealistas).

\section{CIERRE}

A modo de conclusión, vale la pena preguntarnos: ¿en qué momento estos juguetes, estos juegos, estas recuperaciones de la niñez, entran en contacto con los espacios ruinosos, con esas vidas que acusan la vejez y el paso del tiempo, que también caracterizan la obra de Couve? ¿Si Camondo de cera es un juguetito - un juguete de los dioses-, cómo entender su condición última de "categórico despojo" (435)? Creemos que Agamben, en "El país de los juguetes", da con la clave al decir: "El carácter esencial del juguete -en última instancia el único que puede distinguirlo de los demás objetoses algo que solamente puede captarse en la dimensión temporal de un una vez y un ya no más [...]. El juguete es algo que perteneció -una vez, ya no más- a la esfera de lo sagrado o a la esfera práctica-económica" (101-2). El juguete, en este sentido, será una especie de testimonio del mundo caído en la historia: "[e]l juguete, fragmentando y tergiversando el pasado o bien miniaturizando el presente [...] vuelve tangible la temporalidad humana 
en sí misma..." (103). Por eso, se nos dice, "el juguete también se sirve de 'residuos' y 'fragmentos'...” (103).

Entrar a Couve por la vía de los juegos de la infancia y los juguetes no sería, por tanto, una forma de ofrecer una versión edulcorada de su obra o una suerte de relato para niños, limpio de toda tragedia; más bien, se trata de una operación cercana a la arqueología. Después de todo, no hemos hecho otra cosa que hablar de dominios perdidos, objetos rotos que interpelan nuestra modernidad (como Cartagena): Coré y la revista El peneca (fuera de circulación hace años; las láminas recuperadas de Coré son apenas "el resto de un naufragio de papel y tinta", dice Lihn, lamentando las muchísimas imágenes extraviadas ["El retorno de Coré" 465]); el franciscano de madera que ha perdido sus manos (o su cabeza); los muñecos de trapo y los trenes de cuerda -en fin, todos objetos en desuso a los que se aferra el yo.

\section{BIBLIOGRAFÍA}

Abussabbha, Nazario et al. Coré al museo. Seminario de investigación. Universidad de Chile, 1983.

Agamben, Giorgio. "El país de los juguetes. Reflexiones sobre la historia y el juego". Infancia e historia: destrucción de la experiencia y origen de la historia. Buenos Aires: Adriana Hidalgo Editora, 2007. 93-128.

"Parodia". Profanaciones. Trad. Flavia Costa y Edgardo Castro. Buenos Aires: Adriana Hidalgo Editora, 2005. 47-63.

Arikha, Avigdor. "Reflexión sobre Poussin". Cartas y consideraciones en torno al arte. Trad. Lydia Vásquez. Madrid: Visor, 1995.

Barthes, Roland. El susurro del lenguaje: más allá de la palabra y la escritura. Trad. C. Fernández Medrano. Barcelona: Paidós, 1987.

Baudelaire, Charles. "La moral del juguete". Salones y otros escritos sobre arte. Trad. Carmen de Santos. Madrid: Visor, 1999.

Benjamin, Walter. "Juguetes antiguos". Escritos: la literatura infantil, los niños y los jóvenes. Trad. Juan J. Thomas. Buenos Aires: Editorial Nueva Visión, 1989. 79-83.

Libro de los pasajes. Ed. Rolf Tiedemann. Trad. Luis Fernández Castañeda, Isidro Herrera y Fernando Guerrero. Madrid: Ediciones Akal, 2005.

Caillois, Roger. Los juegos y los hombres: la máscara y el vértigo. Trad. Jorge Ferreiro. México, D.F.: Fondo de Cultura Económica, 1988.

Campaña, Claudia. Adolfo Couve: una lección de pintura. Santiago: Eco, 2002.

Cervantes, Miguel de. Don Quijote de la mancha vol. 2. Madrid: Taller Tipográfico, 1856.

Coré. Coré. Ed. Juan Domingo Marinello. Santiago: Ediciones B, 2006. 
Cortázar, Julio. “Acefalia”. Historias de cronopios y famas. Buenos Aires: Alfaguara, 2000. 41.

Couve, Adolfo. "En los desórdenes de junio". Narrativa completa. Santiago: Seix Barral, 2003. 29-52.

"El picadero". Narrativa completa. Santiago: Seix Barral, 2003. 53-106.

"El tren de cuerda". Narrativa completa. Santiago: Seix Barral, 2003. 107-152.

"La lección de pintura". Narrativa completa. Santiago: Seix Barral, 2003. 171-208. "El pasaje”. Narrativa completa. Santiago: Seix Barral, 2003. 209-250.

"Balneario". Narrativa completa. Santiago: Seix Barral, 2003. 303-314.

"La Comedia del Arte”. Narrativa completa. Santiago: Seix Barral, 2003. 361-432.

"Cuando pienso en mi falta de cabeza (La segunda comedia)". Narrativa completa.

Santiago: Seix Barral, 2003. 433-477.

"Prólogo". Cuarteto de la infancia. Buenos Aires: Seix Barral, 1996. 7-10.

“Autorretrato de artista”. Entrevista de Claudia Donoso. Revista Paula 1998. 20

de junio de 2011. http://www.letras.s5.com/couvebiografia.htm

Eco, Umberto. Los límites de la interpretación. Trad. Helena Lozano. Barcelona: Lumen, 1992.

Huizinga, Johan. Homo ludens. Trad. Eugenio Imaz. Madrid: Alianza Editorial, 2007. Impreso.

Lihn, Enrique. "La magia de Coré". Textos sobre arte. Ed. Adriana Valdés y Ana María Risco.

Santiago: Ediciones Universidad Diego Portales, 2008. 460-463.

"El retorno de Coré". Textos sobre arte. Ed. Adriana Valdés y Ana María Risco.

Santiago: Ediciones Universidad Diego Portales, 2008. 464-473.

Peña Muñoz, Manuel. Historia de la literatura infantil chilena. Santiago: Editorial Andrés Bello, 1982.

Pérez Villalón, Fernando. "Escenas de Adolfo Couve (estudio en cinco miradas)". Cyber Humanitatis 28 (2003). 20 de junio de 2011. www.revistas.uchile.cl/index.php/RHC/ article/view/5710/5578

Romera, Antonio R. Historia de la pintura chilena. Santiago: Zig-Zag, 1968.

Valdés, Adriana. “Adolfo Couve, narrador de lo inquietante". Narrativa completa. De Adolfo Couve. Santiago: Seix Barral, 2003. 7-14.

"Prólogo". Cuando pienso en mi falta de cabeza. De Adolfo Couve. Santiago: Seix Barral, 2000. 7-29.

Yurkievich, Saúl. "Conversatorio". Otra flor amarilla: homenaje a Julio Cortázar. México, D.F.: Universidad de Guadalajara, 2002. 13-26.

“Mate, tango y metafísica”. Inti: Revista de literatura hispánica 22 (1985): 1-7. 